\title{
The effects of maternal calving date and calving interval on growth performance of beef calves
}

\author{
R.G. MacGregor ${ }^{1 *}$ and N.H. Casey \\ Department of Animal and Wildlife Science, University of Pretoria, Pretoria 0002, South Africa.
}

\begin{abstract}
This study was undertaken to investigate the growth performance of calves born to dams with different calving dates and calving intervals. Early calving dams produced calves with the lowest birth weights, the highest actual weaning weights and the highest pre-breeding heifer weights. The higher weaning weights of early calvers were due to higher pre-weaning average daily gains and the older age of their calves at weaning. Corrected weaning weights of calves born to dams calving at different times during the calving season were not significantly different. A one-day increase in calving interval resulted in a decrease of $0.29 \pm 0.01 \mathrm{~kg}$ for weaning weight and a decrease of $0.54 \pm 0.01$ $\mathrm{kg}$ for heifer pre-breeding weight. It is recommended that date of calving and actual weaning weight of calves should be considered when evaluating the reproductive and productive performance of breeding cows.
\end{abstract}

Keywords: calving date, calving interval, growth rate, beef cows

*Author to whom correspondence should be addressed. ${ }^{1}$ Present address: Heifer Project - South Africa, P O Box 1770, Hillcrest, 3650, South Africa; E-mail: hpsagm@mweb.co.za

\section{Introduction}

The profitability of the beef-calf production enterprise depends on reproductive efficiency, pre- and post-weaning growth rate and the efficiency of feed utilization. Calving interval is a biased measure of evaluating reproductive performance in beef cows mated during a restricted breeding season, due to the large negative effect of previous calving date on calving interval (Bourdon \& Brinks, 1983; MacGregor, 1997; MacGregor \& Casey, 1999). In addition, it has been shown that cows with the shortest calving intervals produce the lightest weaners (Hetzel et al., 1989; Swanepoel et al., 1992; Swanepoel \& Hoogenboezem, 1994). It has been proposed that calving date is a more suitable measure when cows are mated during a restricted breeding season (Bourdon \& Brinks, 1983; MacGregor, 1997; MacGregor \& Casey, 1999), however, there is a need to determine how the use of calving date as a measure of reproductive performance influences the subsequent growth performance of calves. This study was conducted to compare the growth performance of calves born to cows calving at different times during the calving season with that of calves born to cows with different calving intervals.

\section{Material and Methods}

The data for this study were derived from a synthetic Bovelder herd kept at the Olifantsvlei farm of the Johannesburg Municipality. Irrigated Ryegrass (Lolium spp.) and Kikuyu (Pennisetum clandestinum) pastures constituted the main forages. Cows calved from 1 July to 31 October, which corresponded with the period of peak fodder production. Calves were weaned at approximately seven months of age, when bull calves were separated from heifers. Heifers were allocated to one of two groups according to weaning weight: the low weight group (165-225 kg) were fed an additional $3 \mathrm{~kg}$ of concentrate for 120 days, and the high weight group received an additional $2 \mathrm{~kg}$ of concentrate for 100 days. All mating was by artificial insemination. Vasectomised teaser bulls were used for heat detection, and heat observation was conducted for 24 hours daily during the breeding season. Heifers were mated at 14 months of age (approximately $308 \mathrm{~kg}$ ). Heifers were bred for 50 days starting 15 days before the main herd whilst cows were bred for 60 days. Further details of herd and management practices are given in Paterson (1981). In this study calving date refers to the time a cow calves during a well-planned calving season, and does not advocate early calving during the year. Only data from cows with two or more consecutive calving records were used, and data from cows that did not calve were excluded from the analysis. Calving date was categorised into five groups as shown in Table 1. Previous calving group of the dam was categorised in the same way.

Data were analysed using a general linear models procedure (SAS, 1985). Traits were analysed by least square means of variance. Two models were developed. The following independent variables were used for model 1: year of birth, age of dam, sex of calf, previous calving group of the dam, calving group and birth weight of calf. Model 2 included the same variables as model 1, but calving group was replaced by calving interval. Birth weight of the calf and calving interval were included in the analysis as co-variables. The dependent variables tested in each model were: 
birth weight, actual weaning weight, pre-weaning average daily gain, age at weaning, corrected weaning weight, prebreeding heifer weight and post-weaning average daily gain.

Table 1 Distribution of calving dates and assignment of categories to data used for the analysis of growth performance of beef calves

\begin{tabular}{ccccc}
\hline $\begin{array}{c}\text { Calving } \\
\text { group }\end{array}$ & $\begin{array}{c}\text { Period } \\
\text { (days from the } \\
\text { beginning of the } \\
\text { calving season) }\end{array}$ & $\begin{array}{c}\text { Duration } \\
(\mathrm{d})\end{array}$ & $\begin{array}{c}\text { Number of } \\
\text { observations }\end{array}$ & Percentage of total \\
\hline & & & & \\
1 & $1-31$ & 30 & 1078 & 6.4 \\
2 & $32-52$ & 20 & 6801 & 40.4 \\
3 & $53-74$ & 21 & 5637 & 33.5 \\
4 & $75-95$ & 20 & 2707 & 16.1 \\
5 & $96-123$ & 47 & 625 & 3.7 \\
\hline
\end{tabular}

\section{Results and Discussion}

All variables included in the models influenced calf birth weight $(p<0.01)$. Seven-year-old cows produced calves with the highest birth weights, while three-year-old cows produced calves with the lowest birth weights in both models (Table 2). Using data from the same herd, Paterson (1978) found that birth weight increased with age of dam up to five years and declined after eight years. Birth weights were lowest for calves born to dams that had calved in the earliest group during the previous year whilst birth weight was higher $(p<0.01)$ for cows that calved later (Table 2 , model1). A one-day increase in calving interval resulted in an increase $(p<0.01)$ in birth weight of $0.06 \pm 0.003 \mathrm{~kg}$ (Table 2, model 2).

Actual weaning weight, corrected weaning weight, pre-weaning average daily gain and age at weaning were affected by all variables included in both models $(p<0.01)$, except previous calving group in the case of model 1 (Tables $3 \& 4)$. All variables included in model 2 influenced age at weaning $(p<0.01)$ except birth weight of calf (Tables $3 \& 4$ ). Nine-year-old dams produced calves with the highest actual and corrected weaning weights and the highest average daily gains from birth to weaning in both models, while three-year-old dams produced the lightest weaners, which had the lowest pre-weaning average daily gains in both models (Tables 3 \& 4). Paterson (1978), analyzing data from the same farm, found that five and six-year-old dams produced the heaviest actual weaning weights with five year old cows producing calves with the highest pre-weaning average daily gains. Bull calves in both models attained higher $(p<0.01)$ actual and corrected weaning weights and pre-weaning average daily gains than either steers or heifers (Tables $3 \& 4$ ). Heifers attained higher weaning weights and average daily gains than steers $(p<0.01$ ), which is contrary to what would be expected. This can be explained by the fact that very few steers were included in the data set (2029 steers, 6792 bulls and 8306 heifers), since most bull calves were left intact for bull performance testing and selection.

The fact that previous date of calving of the dam had an effect in the model that included calving interval (model 1) and no effect in the model that included calving group (model 2) is expected, as calving interval is a function of previous calving date. Others (Bourdon \& Brinks, 1983; MacGregor, 1995; MacGregor, 1997; MacGregor \& Casey, 1999) reported that previous calving date of the dam had a greater influence on calving interval than on calving date. Cows calving in group 1 produced the heaviest weaners $(p<0.01)$, which were $27.96 \mathrm{~kg}$ heavier than cows calving in group 5 ( $p<0.01$; Table 3$)$. This was because early born calves had higher pre-weaning average daily gains $(p<0.01)$ and were older at weaning than calves born later $(p<0.01)$. Others have also reported that early calving cows produced heavier weaners (Morris \& Cullen, 1988; Marshall et al., 1990; Garcia Paloma et al., 1992; Rege \& Famula, 1993). The higher pre-weaning average daily gains of early born calves are significant, as it has been reported that heifers experiencing faster pre-weaning growth rates reach puberty at younger ages and heavier weights than slower growing contemporaries (Wiltbank et al., 1966; Brown et al., 1972; Laster et al., 1972; Swierstra et al., 1977). 
Table 2 The effects of age of dam, sex of calf, calving group of dam and previous calving group of dam on calf birth weight ( \pm s.d.)

\begin{tabular}{|c|c|c|}
\hline Effect & $\begin{array}{l}\text { Birth weight (kg) } \\
\text { Model } 1\end{array}$ & $\begin{array}{c}\text { Birth weight }(\mathrm{kg}) \\
\text { Model } 2\end{array}$ \\
\hline $\begin{array}{l}\text { Age of Dam } \\
\text { (years) }\end{array}$ & $* *$ & $* *$ \\
\hline 3 & $34.88 \pm 0.17^{b}$ & $35.37 \pm 0.16^{\mathrm{a}}$ \\
\hline 4 & $36.67 \pm 0.17^{\mathrm{c}}$ & $37.25 \pm 0.17^{\mathrm{b}}$ \\
\hline 5 & $37.69 \pm 0.19^{\mathrm{de}}$ & $38.27 \pm 0.18^{\mathrm{c}}$ \\
\hline 6 & $38.00 \pm 0.19^{\mathrm{ef}}$ & $38.60 \pm 0.18^{\mathrm{cd}}$ \\
\hline 7 & $38.11 \pm 0.21^{\mathrm{f}}$ & $38.68 \pm 0.19^{\mathrm{de}}$ \\
\hline 8 & $37.98 \pm 0.23^{\mathrm{df}}$ & $38.60 \pm 0.22^{\mathrm{cd}}$ \\
\hline 9 & $37.69 \pm 0.26^{\mathrm{df}}$ & $38.27 \pm 0.25^{\mathrm{cd}}$ \\
\hline $10+$ & $37.10 \pm 0.22^{\mathrm{g}}$ & $37.77 \pm 0.21^{\mathrm{e}}$ \\
\hline Sex of calf & $* *$ & $* *$ \\
\hline Bull & $38.70 \pm 0.15^{\mathrm{a}}$ & $39.29 \pm 0.14^{\mathrm{a}}$ \\
\hline Heifer & $35.83 \pm 0.15^{\mathrm{b}}$ & $36.41 \pm 0.14^{\mathrm{b}}$ \\
\hline Calving Group & $* *$ & \\
\hline 1 & $32.81 \pm 0.33^{\mathrm{a}}$ & \\
\hline 2 & $36.32 \pm 0.15^{\mathrm{b}}$ & \\
\hline 3 & $37.84 \pm 0.15^{\mathrm{c}}$ & \\
\hline 4 & $38.87 \pm 0.16^{\mathrm{d}}$ & \\
\hline 5 & $40.49 \pm 0.30^{\mathrm{e}}$ & \\
\hline Previous & & \\
\hline Calving Group & $* *$ & $* *$ \\
\hline 1 & $36.59 \pm 0.24^{\mathrm{a}}$ & $34.93 \pm 0.24^{\mathrm{a}}$ \\
\hline 2 & $37.28 \pm 0.15^{\mathrm{b}}$ & $36.72 \pm 0.13^{\mathrm{b}}$ \\
\hline 3 & $37.64 \pm 0.15^{\mathrm{c}}$ & $38.17 \pm 0.13^{c}$ \\
\hline 4 & $37.50 \pm 0.18^{\mathrm{bc}}$ & $39.20 \pm 0.17^{\mathrm{d}}$ \\
\hline 5 & $37.33 \pm 0.35^{\mathrm{abc}}$ & $40.23 \pm 0.36^{\mathrm{e}}$ \\
\hline $\begin{array}{c}\text { Covariates } \\
\text { Calving Interval }\end{array}$ & & $0.06 \pm 0.003^{* *}$ \\
\hline
\end{tabular}

\footnotetext{
$* *$ Significance of main effects $(p<0.01) ;{ }^{\text {a-e }}$ means without common superscripts within the same column and effect category differ $(p<0.05)$
}

Calving group influenced $(p<0.01)$ corrected weaning weight (Table 3$)$. In contrast to the effect on actual weaning weight (Table 3), corrected weaning weights did not differ between cows calving earliest (group 1) and those calving later. This disparity is an effect of the correction of weaning weight for age of calf. In the correction of actual weaning weights for the age of the calves, the earliest calvers are disadvantaged whilst the late calvers are favoured (MacGregor, 1997). The actual weaning weight of an early born calf is usually significantly reduced when corrected whilst a very small change in weight occurs for a late born calf. Rege \& Moyo (1993) also found that the corrected weaning weights of calves born to cows calving early did not differ from that of cows calving later, but the net weight gain from birth to weaning was found to be highest for calves born earliest. In the present study, a one-day increase in calving interval was associated with a decrease of $0.29 \pm 0.01 \mathrm{~kg}$ in weaning weight and a decrease of $0.08 \pm 0.01$ $\mathrm{kg}$ in corrected weaning weight. Hetzel et al. (1989), Swanepoel et al. (1992) and Swanepoel \& Hoogenboezem (1994) found that cows with the shortest calving intervals produced lighter weaners than cows with longer calving intervals. Doren et al. (1986) concluded that weaning weight of the previous calf influences calving interval, in that higher weaning weights were associated with longer calving intervals. A one-kg increase in birth weight resulted in an increase of $2.13 \pm 0.05 \mathrm{~kg}$ in weaning weight and an increase of $2.06 \pm 0.04 \mathrm{~kg}$ in corrected weaning weight. A one- $\mathrm{kg}$ increase in birth weight resulted in an increase of $0.005 \pm 0.0002 \mathrm{~kg}$ in pre-weaning average daily gain and a decrease of 0.05 \pm 0.02 days in age at weaning, since heavier birth weights were associated with later calving (Table 3 ). 
Table 3 The effects of age of dam, sex of calf, calving group of dam and previous calving group of dam on actual weaning weight, 210 day corrected weaning weight, pre-weaning average daily gain (ADG) and age at weaning for model 1 ( \pm s.d.)

\begin{tabular}{|c|c|c|c|c|}
\hline Effect & $\begin{array}{c}\text { Weaning weight } \\
(\mathrm{kg})\end{array}$ & $\begin{array}{c}210 \text { day Corrected } \\
\text { Weaning Weight } \\
(\mathrm{kg})\end{array}$ & $\begin{array}{c}\text { Pre-weaning } \\
\text { ADG } \\
(\mathrm{kg})\end{array}$ & $\begin{array}{c}\text { Age at } \\
\text { Weaning } \\
\text { (days) }\end{array}$ \\
\hline $\begin{array}{l}\text { Age of Dam } \\
\text { (years) }\end{array}$ & $* *$ & $* *$ & $* *$ & $* *$ \\
\hline 3 & $220.08 \pm 0.93^{\mathrm{a}}$ & $205.93 \pm 0.85^{\mathrm{b}}$ & $0.80 \pm 0.004^{\mathrm{b}}$ & $228.85 \pm 0.33^{\mathrm{b}}$ \\
\hline 4 & $220.94 \pm 0.94^{\mathrm{ac}}$ & $206.66 \pm 0.86^{\mathrm{b}}$ & $0.80 \pm 0.004^{\mathrm{b}}$ & $228.87 \pm 0.34^{b}$ \\
\hline 5 & $225.36 \pm 0.99^{d}$ & $210.65 \pm 0.90^{c}$ & $0.82 \pm 0.004^{\mathrm{c}}$ & $228.89 \pm 0.35^{\mathrm{b}}$ \\
\hline 6 & $225.86 \pm 1.01^{\mathrm{d}}$ & $210.33 \pm 0.92^{c}$ & $0.82 \pm 0.004^{\mathrm{c}}$ & $229.63 \pm 0.36^{\mathrm{c}}$ \\
\hline 7 & $227.94 \pm 1.08^{\mathrm{f}}$ & $212.97 \pm 0.98^{d}$ & $0.83 \pm 0.004^{\mathrm{e}}$ & $228.94 \pm 0.39^{\mathrm{bcd}}$ \\
\hline 8 & $228.24 \pm 1.19^{\mathrm{fg}}$ & $213.93 \pm 1.09^{\mathrm{de}}$ & $0.84 \pm 0.005^{\mathrm{ef}}$ & $228.26 \pm 0.43^{\mathrm{bd}}$ \\
\hline 9 & $230.74 \pm 1.34^{\mathrm{g}}$ & $216.03 \pm 1.22^{\mathrm{e}}$ & $0.83 \pm 0.005^{\mathrm{f}}$ & $228.38 \pm 0.48^{\mathrm{bd}}$ \\
\hline $10+$ & $227.18 \pm 1.16^{\mathrm{df}}$ & $212.95 \pm 1.06^{\mathrm{d}}$ & $0.83 \pm 0.005^{\mathrm{e}}$ & $228.15 \pm 0.41^{\mathrm{bd}}$ \\
\hline Sex of calf & $* *$ & $* *$ & $* *$ & $* *$ \\
\hline Bull & $238.81 \pm 0.83^{\mathrm{a}}$ & $223.56 \pm 0.75^{\mathrm{a}}$ & $0.89 \pm 0.003^{\mathrm{a}}$ & $229.34 \pm 0.29$ \\
\hline Heifer & $221.67 \pm 0.81^{\mathrm{b}}$ & $206.88 \pm 0.74^{\mathrm{b}}$ & $0.81 \pm 0.003^{\mathrm{b}}$ & $228.20 \pm 0.29$ \\
\hline Steer & $216.90 \pm 1.09^{\mathrm{c}}$ & $203.11 \pm 1.00^{\mathrm{c}}$ & $0.79 \pm 0.005^{\mathrm{c}}$ & $228.69 \pm 0.39$ \\
\hline Calving Group & $* *$ & $* *$ & $* *$ & $* *$ \\
\hline 1 & $239.89 \pm 1.78^{\mathrm{a}}$ & $212.36 \pm 1.61^{\mathrm{ac}}$ & $0.83 \pm 0.007^{\mathrm{ac}}$ & $244.63 \pm 0.63^{\mathrm{a}}$ \\
\hline 2 & $230.97 \pm 0.80^{b}$ & $214.44 \pm 0.73^{c}$ & $0.84 \pm 0.003^{c}$ & $230.60 \pm 0.28^{b}$ \\
\hline 3 & $228.21 \pm 0.78^{c}$ & $209.86 \pm 0.71^{\mathrm{a}}$ & $0.82 \pm 0.003^{\mathrm{a}}$ & $232.93 \pm 0.28^{\mathrm{c}}$ \\
\hline 4 & $217.96 \pm 0.87^{\mathrm{d}}$ & $209.87 \pm 0.79^{\mathrm{a}}$ & $0.82 \pm 0.004^{\mathrm{a}}$ & $220.88 \pm 0.31^{\mathrm{d}}$ \\
\hline 5 & $211.93 \pm 1.57^{\mathrm{e}}$ & $209.38 \pm 1.42^{\mathrm{a}}$ & $0.82 \pm 0.007^{\mathrm{a}}$ & $214.69 \pm 0.55^{\mathrm{e}}$ \\
\hline Previous & & & & \\
\hline Calving Group & NS & NS & NS & NS \\
\hline 1 & $224.55 \pm 1.26^{\mathrm{a}}$ & $210.19 \pm 1.15^{\mathrm{a}}$ & $0.82 \pm 0.005^{\mathrm{a}}$ & $228.49 \pm 0.45^{\mathrm{a}}$ \\
\hline 2 & $226.02 \pm 0.79^{\mathrm{a}}$ & $211.31 \pm 0.77^{\mathrm{a}}$ & $0.83 \pm 0.003^{\mathrm{a}}$ & $228.92 \pm 0.28^{\mathrm{a}}$ \\
\hline 3 & $225.79 \pm 0.80^{\mathrm{a}}$ & $211.36 \pm 0.73^{\mathrm{a}}$ & $0.83 \pm 0.003^{\mathrm{a}}$ & $228.48 \pm 0.28^{\mathrm{a}}$ \\
\hline 4 & $224.96 \pm 0.95^{\mathrm{a}}$ & $210.58 \pm 0.87^{\mathrm{a}}$ & $0.82 \pm 0.004^{\mathrm{a}}$ & $228.61 \pm 0.34^{\mathrm{a}}$ \\
\hline 5 & $227.65 \pm 1.82^{\mathrm{a}}$ & $212.47 \pm 1.66^{\mathrm{a}}$ & $0.83 \pm 0.008^{\mathrm{a}}$ & $229.23 \pm 0.65^{\mathrm{a}}$ \\
\hline Covariate & & & & \\
\hline Birth weight & $2.13 \pm 0.05^{* *}$ & $2.07 \pm 0.04^{* *}$ & $0.005 \pm 0.0002^{* *}$ & $-0.05 \pm 0.02^{* *}$ \\
\hline
\end{tabular}

${ }^{3 *}$ Main effects were significant $(p<0.01)$; NS: main effects were not significant $(p<0.05)$; ${ }^{\text {a-e }}$ means without common superscripts within the same column and effect category differ $(p<0.05)$ 
Table 4 The effects of age of dam, sex of calf, calving group of dam and previous calving group of dam on actual weaning weight, 210 day corrected weaning weight, pre-weaning average daily gain (ADG) and age at weaning for model 2 ( \pm s.d.)

\begin{tabular}{|c|c|c|c|c|}
\hline Effect & $\begin{array}{l}\text { Weaning Weight } \\
(\mathrm{kg})\end{array}$ & $\begin{array}{c}210 \text { day } \\
\text { corrected } \\
\text { Weaning Weight }\end{array}$ & $\begin{array}{c}\text { Pre-weaning } \\
\text { ADG }(\mathrm{kg})\end{array}$ & $\begin{array}{c}\text { Age at } \\
\text { Weaning (days) }\end{array}$ \\
\hline $\begin{array}{l}\text { Age of Dam } \\
\text { (years) }\end{array}$ & $* *$ & $* *$ & $* *$ & $*$ \\
\hline 3 & $219.57 \pm 0.86^{\mathrm{ac}}$ & $206.03 \pm 0.78^{\mathrm{a}}$ & $0.80 \pm 0.004^{\mathrm{ac}}$ & $227.92 \pm 0.33^{\mathrm{abc}}$ \\
\hline 4 & $219.85 \pm 0.87^{\mathrm{c}}$ & $206.60 \pm 0.79^{\mathrm{a}}$ & $0.81 \pm 0.004^{\mathrm{c}}$ & $227.39 \pm 0.33^{\mathrm{b}}$ \\
\hline 5 & $224.42 \pm 0.93^{\mathrm{d}}$ & $210.61 \pm 0.84^{c}$ & $0.82 \pm 0.004^{\mathrm{b}}$ & $227.58 \pm 0.35^{\mathrm{ab}}$ \\
\hline 6 & $224.84 \pm 0.94^{\mathrm{d}}$ & $210.23 \pm 0.86^{\mathrm{c}}$ & $0.82 \pm 0.004^{\mathrm{b}}$ & $228.29 \pm 0.36^{\mathrm{a}}$ \\
\hline 7 & $227.09 \pm 1.02^{\mathrm{b}}$ & $212.79 \pm 0.93^{\mathrm{b}}$ & $0.83 \pm 0.004^{\mathrm{b}}$ & $227.92 \pm 0.39^{\mathrm{a}}$ \\
\hline 8 & $227.38 \pm 1.14^{\text {be }}$ & $213.74 \pm 1.03^{\mathrm{bd}}$ & $0.84 \pm 0.005^{\mathrm{b}}$ & $227.30 \pm 0.43^{\text {bd }}$ \\
\hline 9 & $229.91 \pm 1.29^{\mathrm{e}}$ & $215.96 \pm 1.18^{\mathrm{d}}$ & $0.85 \pm 0.006^{\mathrm{b}}$ & $227.22 \pm 0.49^{\text {bd }}$ \\
\hline $10+$ & $226.03 \pm 1.10^{\mathrm{bd}}$ & $212.75 \pm 1.01^{\mathrm{b}}$ & $0.83 \pm 0.005^{\mathrm{b}}$ & $226.81 \pm 0.42^{\mathrm{bcd}}$ \\
\hline Sex of calf & $* *$ & $* *$ & $* *$ & $* *$ \\
\hline Bull & $238.04 \pm 0.74^{\mathrm{a}}$ & $223.45 \pm 0.67^{\mathrm{a}}$ & $0.88 \pm 0.003^{\mathrm{a}}$ & $227.20 \pm 0.28$ \\
\hline Heifer & $220.71 \pm 0.73^{b}$ & $206.70 \pm 0.66^{\mathrm{b}}$ & $0.81 \pm 0.003^{b}$ & $228.18 \pm 0.28$ \\
\hline Steer & $215.91 \pm 1.04^{\mathrm{c}}$ & $203.11 \pm 0.95^{\mathrm{c}}$ & $0.79 \pm 0.004^{\mathrm{c}}$ & $227.28 \pm 0.39$ \\
\hline \multicolumn{5}{|l|}{ Previous Calving } \\
\hline Group & $* *$ & $* *$ & $* *$ & $* *$ \\
\hline 1 & $234.37 \pm 1.28^{\mathrm{a}}$ & $213.37 \pm 1.16^{\mathrm{ac}}$ & $0.84 \pm 0.005^{\mathrm{a}}$ & $236.16 \pm 0.49^{\mathrm{ac}}$ \\
\hline 2 & $230.66 \pm 0.71^{\mathrm{b}}$ & $212.93 \pm 0.65^{\mathrm{ac}}$ & $0.83 \pm 0.003^{b}$ & $232.27 \pm 0.27^{\mathrm{c}}$ \\
\hline 3 & $225.23 \pm 0.71^{\mathrm{c}}$ & $211.38 \pm 0.64^{\mathrm{cd}}$ & $0.83 \pm 0.003^{c}$ & $227.57 \pm 0.27^{\mathrm{ad}}$ \\
\hline 4 & $218.46 \pm 0.93^{\mathrm{d}}$ & $208.79 \pm 0.84^{\mathrm{b}}$ & $0.81 \pm 0.004^{\mathrm{d}}$ & $222.79 \pm 0.35^{\mathrm{b}}$ \\
\hline 5 & $215.71 \pm 1.86^{\mathrm{d}}$ & $208.97 \pm 1.69^{\mathrm{bd}}$ & $0.82 \pm 0.008^{\mathrm{e}}$ & $218.98 \pm 0.71^{\mathrm{bd}}$ \\
\hline \multicolumn{5}{|l|}{ Covariate } \\
\hline Birth weight & $2.13 \pm 0.05^{* *}$ & $2.06 \pm 0.04^{* *}$ & $-0.005 \pm 0.0002^{* *}$ & $-0.03 \pm 0.02$ \\
\hline Calving interval & $-0.29 \pm 0.01^{* *}$ & $-0.08 \pm 0.01^{* *}$ & $-0.0004 \pm 0.0001^{* *}$ & $-0.25 \pm 0.005^{* *}$ \\
\hline
\end{tabular}

\footnotetext{
${ }^{* *}$ Main effects were significant $(p<0.01) ;{ }^{*}$ main effects were significant $(p<0.05) ;{ }^{\text {a-e }}$ means without common superscripts within the same column and effect category differ $(p<0.05)$

Age of dam influenced pre-breeding heifer weight in model $2(p<0.05)$ but not in model $1(p>0.05$; Table 5). Age of dam had no effect on post-weaning average daily gain in either model (Table 5). Cows calving earliest (group $1)$ produced heifers with higher $(p<0.01)$ pre-breeding weights and higher post-weaning average daily gains $(p<0.01)$ than cows calving later (Table 5). Heifers born to dams that calved in group 1 were $43.92 \mathrm{~kg}$ heavier at pre-breeding weighing than heifers born to cows which calved in group 5. This finding has significant implications in the light of the well known relationship between body weight and fertility (Lishman et al., 1984; MacGregor \& Swanepoel, 1992) in which heifers normally have problems attaining a minimum target weight. In addition to this, a higher weight at 12 months represents potential additional income that could be derived from the sale of female slaughter animals.
} 
Table 5: The effects of age of dam, calving group of dam and previous calving group of dam on heifer pre-breeding weight and post-weaning average daily gain (ADG) $( \pm$ s.d.)

\begin{tabular}{|c|c|c|c|c|}
\hline \multirow[t]{2}{*}{ Effect } & \multicolumn{2}{|c|}{ Heifer pre-breeding weight $(\mathrm{kg})$} & \multicolumn{2}{|c|}{ Heifer post-weaning ADG $(\mathrm{kg})$} \\
\hline & model 1 & model 2 & model 1 & model 2 \\
\hline $\begin{array}{l}\text { Age of Dam } \\
\text { (years) }\end{array}$ & N S & $*$ & N S & N S \\
\hline 3 & $312.39 \pm 0.95^{\mathrm{b}}$ & $312.37 \pm 0.87^{\mathrm{a}}$ & $0.52 \pm 0.03^{\mathrm{a}}$ & $0.52 \pm 0.02^{\mathrm{a}}$ \\
\hline 4 & $312.38 \pm 0.94^{\mathrm{b}}$ & $312.11 \pm 0.87^{\mathrm{a}}$ & $0.52 \pm 0.03^{\mathrm{a}}$ & $0.51 \pm 0.02^{\mathrm{a}}$ \\
\hline 5 & $311.73 \pm 1.04^{\mathrm{ab}}$ & $310.67 \pm 0.97^{\mathrm{ab}}$ & $0.51 \pm 0.03^{\mathrm{a}}$ & $0.50 \pm 0.03^{\mathrm{a}}$ \\
\hline 6 & $313.25 \pm 1.07^{\mathrm{b}}$ & $312.57 \pm 1.00^{\mathrm{a}}$ & $0.51 \pm 0.03^{\mathrm{a}}$ & $0.51 \pm 0.03^{\mathrm{a}}$ \\
\hline 7 & $310.90 \pm 1.18^{\mathrm{ab}}$ & $309.99 \pm 1.13^{\mathrm{ac}}$ & $0.50 \pm 0.03^{\mathrm{a}}$ & $0.49 \pm 0.03^{\mathrm{a}}$ \\
\hline 8 & $309.38 \pm 1.37^{\mathrm{a}}$ & $308.68 \pm 1.33^{\mathrm{bc}}$ & $0.49 \pm 0.04^{\mathrm{a}}$ & $0.48 \pm 0.04^{\mathrm{a}}$ \\
\hline 9 & $308.95 \pm 1.54^{\mathrm{a}}$ & $308.48 \pm 1.50^{\mathrm{bc}}$ & $0.49 \pm 0.04^{\mathrm{ab}}$ & $0.49 \pm 0.04^{\mathrm{a}}$ \\
\hline $10+$ & $310.73 \pm 1.35^{\mathrm{ab}}$ & $309.62 \pm 1.31^{\mathrm{ac}}$ & $0.63 \pm 0.04^{\mathrm{b}}$ & $0.62 \pm 0.04^{\mathrm{b}}$ \\
\hline Calving Group & $* *$ & & $* *$ & \\
\hline 1 & $331.80 \pm 1.86^{\mathrm{a}}$ & & $0.64 \pm 0.06^{\mathrm{a}}$ & \\
\hline 2 & $326.03 \pm 0.74^{b}$ & & $0.59 \pm 0.04^{\mathrm{a}}$ & \\
\hline 3 & $311.05 \pm 0.72^{\mathrm{c}}$ & & $0.53 \pm 0.04^{\mathrm{b}}$ & \\
\hline 4 & $299.31 \pm 0.91^{\mathrm{d}}$ & & $0.49 \pm 0.04^{\mathrm{b}}$ & \\
\hline 5 & $287.88 \pm 1.80^{\mathrm{e}}$ & & $0.44 \pm 0.06^{\mathrm{b}}$ & \\
\hline Previous & N S & & NS & $* *$ \\
\hline Calving Group & & & & \\
\hline 1 & $312.93 \pm 1.40^{\mathrm{a}}$ & $332.79 \pm 1.46^{\mathrm{a}}$ & $0.55 \pm 0.05^{\mathrm{a}}$ & $0.62 \pm 0.04^{\mathrm{a}}$ \\
\hline 2 & $311.40 \pm 0.71^{\mathrm{ab}}$ & $321.57 \pm 0.62^{b}$ & $0.55 \pm 0.04^{\mathrm{a}}$ & $0.58 \pm 0.02^{\mathrm{a}}$ \\
\hline 3 & $310.14 \pm 0.73^{b}$ & $310.66 \pm 0.61^{c}$ & $0.52 \pm 0.04 \quad$ a & $0.51 \pm 0.02^{\mathrm{b}}$ \\
\hline 4 & $309.52 \pm 0.95^{\mathrm{b}}$ & $297.99 \pm 0.96^{\mathrm{d}}$ & $0.53 \pm 0.04^{\mathrm{a}}$ & $0.46 \pm 0.03^{\mathrm{b}}$ \\
\hline 5 & $312.08 \pm 2.12^{\mathrm{ab}}$ & $289.81 \pm 2.22^{\mathrm{e}}$ & $0.54 \pm 0.07^{\mathrm{a}}$ & $0.42 \pm 0.06^{\mathrm{b}}$ \\
\hline Covariate & & & & \\
\hline Birth weight & $1.19 \pm 0.07^{* *}$ & $1.18 \pm 0.07^{* *}$ & $0.006 \pm 0.002^{* *}$ & $0.006 \pm 0.002^{* *}$ \\
\hline Wean weight & $0.64 \pm 0.01^{* *}$ & $0.64 \pm 0.01^{* *}$ & $-0.002 \pm 0.0004^{* *}$ & $-0.002 \pm 0.0004^{* *}$ \\
\hline Calving Interval & & $-0.54 \pm 0.02^{* *}$ & & $-0.002 \pm 0.0005^{* *}$ \\
\hline
\end{tabular}

${ }^{\text {** }}$ Main effects were significant $(p<0.01)$; " main effects were significant $(p<0.05)$; NS: main effects were non-significant $(p>$ $0.05) ;{ }^{\mathrm{a} e}$ means without common superscripts within the same column and effect category differ $(p<0.05)$

Rege \& Famula (1993) found that a delay in calving date was associated with reductions in yearling weight and average daily gain from weaning to 12 months of age. Rege \& Moyo (1993) reported a weight advantage at 12 months for early born calves similar to that found in this study. Mackinnon et al. (1990) who studied the relationship between fertility and growth in two divergent fertility lines (high vs. low), reported that early born animals were heavier at 12 and 18 months than late born animals. They concluded that earlier calving, associated with higher fertility, would have beneficial effects on growth performance in the herd. A one-day increase in calving interval resulted in a decrease of $0.54 \pm 0.01 \mathrm{~kg}$ in the heifer pre-breeding weight (Table 5). In model 2, the effect of previous calving group of the dam on pre-breeding calf weight $(p<0.01)$ resulted in early born calves having higher pre-breeding weights and higher postweaning average daily gains (Table 5). A one-kg increase in calf birth weight resulted in an increase of $1.18 \pm 0.07 \mathrm{~kg}$ in pre-breeding heifer weight, and a one-kg increase in weaning weight resulted in an increase of $0.64 \pm 0.01 \mathrm{~kg}$ in prebreeding heifer weight in both models (Table 5). The $\mathrm{R}^{2}$ values of both models were identical for pre-breeding heifer weight (0.69). Weaning weight of the calf had the greatest effect on pre-breeding heifer weight (excluding the effect of year) in both models and accounted for approximately the same amount of variation in each model (model 1: 15.1\%; model 2: 14.6\%). Calving group (model 1) and calving interval (model 2) had the second greatest influence. 


\section{Conclusions}

Early calving cows produced weaners with higher actual weaning weights, and heifers with higher pre-breeding weights. This effect is, however, obscured when weaning weight is corrected for age. Therefore, if selection is based on corrected weaning weight the most productive cows in the herd may not be identified or retained for breeding purposes. It is recommended that date of calving and actual weaning weight of calves should be considered in evaluating the reproductive and productive performance of breeding cows.

\section{Acknowledgements}

We acknowledge the assistance of D. Holton with data formatting and analysis.

\section{References}

Bourdon, R.M. \& Brinks, J.S., 1983. Calving date versus calving interval as a reproductive measure in beef cattle. J. Anim. Sci. 57, 1412.

Brown, J.E., Brown, C.J. \& Butts, W.T., 1972. Relationships among weights, gains and earliness of maturity in Hereford and Angus females. J. Anim. Sci. 35, 507.

Doren, P.E., Long, C.R. \& Cartwright, T.C., 1986. Factors affecting the relationship between calving interval of cows and weaning weights of calves. J. Anim. Sci. 62, 1194.

Garcia Paloma, J.A., Alberio, R., Miquel, M.C., Grondona, M.O., Carrillo, J. \& Schiersmann, G., 1992. Effect of calving date on lifetime productivity of cows in a winter calving Aberdeen Angus herd. Anim. Prod. 55, 177.

Hetzel, D.J.S., Mackinnon, M.J., Dixon, R. \& Entwistle, K.W., 1989. Fertility in a tropical beef herd divergently selected for pregnancy rate. Anim.Prod. 49, 73.

Laster, D.B., Glimp, H.A. \& Gregory, K.E., 1972. Age and weight at puberty and conception in different breeds and breed-crosses of beef heifers. J. Anim. Sci. 34, 1031.

Lishman, A.W., Lyle, A.D., Smith, V.W. \& Botha, W.A., 1984. Conception rate of beef cows and growth of suckling calves as influenced by date of calving and supplementary feeding. S. Afr. J. Anim. Sci. 14, 10.

MacGregor, R. G. \& Swanepoel, F.J.C., 1992. The relationship between body mass and fertility in Bonsmara breeding females. S. Afr. J. Anim. Sci. 22, 64.

MacGregor, R. G., 1995. Evaluation of calving date and calving interval as measures of reproductive efficiency in beef cows. Jl. S. Afr. vet. Assoc. 66, 235.

MacGregor, R. G., 1997. Evaluation of methods of measuring reproduction and production in beef cows. PhD Thesis, University of Pretoria, South Africa.

MacGregor, R. G. \& Casey, N.H., 1999. Evaluation of calving interval and calving date as measures of reproductive performance in a beef herd. Livest. Prod. Sci. 57, 181 .

Mackinnon, M.J., Hetzel, D.J.S., Corbet, N.J., Bryan, R.P. \& Dixon, R., 1990. Correlated responses to selection for cow fertility in a tropical beef herd. Anim. Prod. 50, 417.

Marshall, D.M., Minqiang, W. \& Freking, B.A., 1990. Relative calving date of first-calf heifers as related to production efficiency and subsequent reproductive performance. J. Anim. Sci. 68, 1812.

Morris, C.A. \& Cullen, N.G., 1988. Oestrus and reproductive performance of early and late calving beef cows. N.Z. J. of Agric. Res. 31, 395.

Paterson, A.G., 1978. Statistical analysis of factors affecting preweaning growth of beef cattle under intensive pasture conditions. M.Sc. Agric. Thesis, University of Pretoria, South Africa.

Rege, J.E.O. \& Famula, T.R., 1993. Factors affecting calving date and its relationship with production traits of Hereford dams. Anim. Prod. 57, 385.

Rege, J.E.O. \& Moyo, S., 1993. Effect of birth date on growth performance of calves of seasonally bred range cattle. J. Anim. Breed. Genet. 110, 209.

SAS, 1985. SAS User's Guide. Carey, North Carolina.

Swanepoel, F.J.C., Seifert, G.W. \& Lubout, P.C., 1992. The relationship of lifetime fertility of Bonsmara cows with growth and scrotal circumference of their calves. Proc. Aust. Assoc. Anim. Breed. Genet., 10, 362.

Swanepoel, F.J.C. \& Hoogenboezem, J.M., 1994. Interrelationships among cow size, lifetime cow fertility, milk production and pre-weaning calf growth in sub-tropically adapted beef cattle. Proc. of the Aust. Soc. of Anim. Prod. 20, 78.

Swierstra, E.E., Rahnfeld, G.W., Cliplef, R.L. \& Strain, J.H., 1977. Age and weight at puberty of crossbred heifers sired by Charolais, Limousin and Simmental bulls. Can. J. Anim. Sci. 57, 697.

Wiltbank, J.N., Gregory, K.E., Swiger, L.A., Ingalls, J.E., Rothlisberger, J.A. \& Koch, R.M., 1966. Effects of heterosis on age and weight at puberty in beef heifers. J. Anim. Sci. 25, 744. 